\title{
Iris Vascular Disorder
}

National Cancer Institute

\section{Source}

National Cancer Institute. Iris Vascular Disorder. NCI Thesaurus. Code C35618.

A vascular disorder or the iris. 